\title{
Penerapan Metode Pembelajaran Drill melalui Typing Master untuk Meningkatkan Keterampilan Mengetik 10 Jari pada Mata Pelajaran Teknologi Perkantoran di SMK Krian 2 Sidoarjo
}

\author{
Khoiriyah, Durinta Puspasari \\ Jurusan Pendidikan Ekonomi, Fakultas Ekonomi, Universitas Negeri Surabaya \\ Jln. Ketintang, Gayungan, Surabaya 60231 \\ E-mail: khoiriyah.17080314008@mhs.unesa.ac.id
}

\begin{abstract}
Abstrak
Ketepatan metode pembelajaran menjadi faktor penting dalam meningkatkan aktivitas dan keterampilan mengetik 10 jari. Guru masih menggunakan metode ceramah dan penugasan dalam pembelajaran mengetik. Sehingga penelitian ini mempunyai tujuan meningkatkan aktivitas siswa dan keterampilan mengetik 10 jari siswa kelas X OTKP 1 dengan menggunakan metode pembelajaran drill. Penelitian ini adalah jenis Penelitian Tindakan Kelas. Instrumen penelitian ini adalah lembar aktivitas siswa dan lembar pengamatan keterampilan mengetik 10 jari. Analisis hasil penelitian mencakup analisis aktivitas siswa daan analisis keterampilan mengetik 10 jari. Hasil penelitian dinyatakan sebagai berikut: pada siklus I, hasil aktivitas siswa secara keseluruhan mendapat rata-rata skor sejumlah 1,89 (kurang baik). Sedangkan hasil keterampilan mengetik 10 jari pada aspek kecepatan sejumlah 61 (cukup baik), pada aspek ketepatan sejumlah $49 \%$ (cukup baik). Pada pada siklus II, hasil aktivitas siswa secara keseluruhan mendapat rata-rata skor sejumlah 2,78 (cukup baik). Sedangkan hasil keterampilan mengetik 10 jari pada aspek kecepatan sejumlah 85 (cukup baik), pada aspek ketepatan sejumlah 74\% (baik). Pada siklus III, hasil aktivitas siswa secara keseluruhan mendapat rata-rata skor sejumlah 3,72 (baik). Sedangkan hasil keterampilan mengetik 10 jari pada aspek kecepatan sejumlah 115 (baik), pada aspek ketepatan sejumlah 90\% (sangat baik). Hasil ini telah menunjukkan adanya peningkatan aktivitas siswa dan keterampilan mengetik 10 jari dari siklus I, II, dan III, serta menunjukkan bahwa penerapan metode pembelajaran drill melalui typing master dapat meningkatkan keterampilan mengetik 10 jari pada mata pelajaran Teknologi Perkantoran kelas X OTKP1 di SMK Krian 2 Sidoarjo.
\end{abstract}

Kata Kunci: Keterampilan Mengetik 10 jari, Metode Pembelajaran drill, Typing Master.

\section{Abstract}

The accuracy of the learning method was an important factor in improving the activity and 10 finger typing skills. Teachers still use the lecture method and assignments in typing learning. So this study has the aim of increasing student activity and 10 finger typing skills of class X OTKP 1 in using the drill learning method. This research is a type of classroom action research. The research instruments were student activity sheets and observation sheets for 10 finger typing skills. The analysis of the research results includes analysis of student activity and analysis of 10 finger typing skills. The results of the study are stated as follows: in the first cycle, the overall results of the students' activities got an average score of 1.89 (less good). While the results of 10 finger typing skills on the speed aspect were 61 (quite good), on the accuracy aspect was 49\% (good enough). In cycle II, the results of student activity as a whole got an average score of 2.78 (good enough). While the results of 10 finger typing skills on the speed aspect were 85 (quite good), on the accuracy aspect was $74 \%$ (good). In cycle III, the results of student activity as a whole got an average score of 3.72 (good). While the results of 10 finger typing skills on the speed aspect were 115 (good), on the accuracy aspect was $90 \%$ (very good). These results have shown an increase in student activity and 10 finger typing skills from cycles I, II, and III, and show that the application of the drill learning method through master typing can improve 10 finger typing skills in Office Technology subject for class X OTKP 1 at SMK Krian 2 Sidoarjo.

Keywords: drill learning method; 10 finger typing skills; typing master.

\section{Pendahuluan}

Pendidikan merupakan faset hakiki yang wajib dimiliki oleh setiap individu. Potensi diri dari setiap orang dapat dikembangkan karena adanya pendidikan. Sebab itu, individu wajib mendapatkan pendidikan agar mereka mampu menerapkannya pada kehidupan sehari-hari serta dapat membentuk pribadi yang berkualitas yang mampu bersaing dengan pribadi lain dalam dunia pendidikan. Sebagai halnya dipaparkan dalam (Undang-Undang No. 20 Tahun 2003 Tentang Sistem Pendidikan Nasional [26], "pendidikan nasional berfungsi mengembangkan kemampuan dan membentuk watak serta peradaban bangsa yang bermartabat dalam rangka mencerdaskan kehidupan bangsa, bertujuan untuk berkembangnya potensi siswa agar menjadi manusia yang beriman dan bertakwa kepada Tuhan Yang Maha Esa, berakhlak mulia, sehat berilmu, cakap, kreatif, mandiri, dan menjadi warga negara yang demokratis serta bertanggung jawab".

SMK Krian 2 Sidoarjo di masa pandemi covid-19 menerapkan pola pembelajaran dalam jaringan (daring) dan luar jaringan (luring), pola ini diterapkan dengan siswa yang 
masuk dibatasi hanya $50 \%$ dengan sistem ganjil genap. Alasan pola ini diterapkan oleh pihak sekolah yakni untuk memaksimalkan pembelajaran, mengingat Sekolah Kejuruan adalah sekolah yang membutuhkan praktik lebih banyak. Dengan begitu, sistem ini sedikit banyak akan membantu siswa memahami dan melakukan praktik pembelajaran dengan baik, namun dengan tidak mengabaikan protokol kesehatan, seperti wajib memakai masker, mencuci tangan dan penyemprotan disinfektan saat akan masuk sekolah, dan jaga jarak.

Berdasarkan studi pendahuluan melalui wawancara dengan Ketua Kejuruan Otomatisasi dan Tata Kelola Perkantoran, dapat diketahui bahwa SMK Krian 2 Sidoarjo adalah sekolah yang berakreditasi A serta memiliki fasilitas yang memadai. Fasilitas yang dimiliki oleh sekolah khususnya pada kejuruan Otomatisasi dan Tata Kelola Perkantoran ini terbilang lengkap. Seperti teknologi perkantoran yang disediakan di laboratorium, diantaranya: komputer, telephone, printer, LCD, digunakan dengan sangat baik dan rutin dilakukan perawatan. Sehingga komputer dan teknologi lain yang tersedia dapat dijalankan secara baik dan bisa mendukung aktivitas siswa khususnya pada mata pelajaran Teknologi Perkantoran.

Teknologi Perkantoran adalah satu diantara pelajaran keahlian di Kejuruan Otomatisasi dan Tata Kelola Perkantoran. Mata pelajaran ini identik dengan teknologi yang ada di perkantoran serta mempelajari bagaimana pemanfaatan dan penggunaan teknologi tersebut. Mulai dari cara penggunaan, mengolah, menghimpun, mencatat, menghitung, mengirim, dan menggandakan. Semua aktivitas tersebut merupakan aktivitas yang setiap hari dilakukan oleh para pekerja kantor. Begitu pula siswa dalam kegiatan pembelajaran juga melakukan kegiatan menghimpun, menghitung, maupun mencatat, baik itu mencatat laporan, makalah, maupun materi pelajaran. Sehingga diperlukan keterampilan penggunaan teknologi oleh siswa, salah satunya adalah komputer yang digunakan untuk mencatat atau mengetik. Menerapkan Pengetikan (Keyboarding) 10 Jari Kecepatan 200 EPM dan Ketepatan 99\% merupakan salah satu kompetensi dasar pada mata pelajaran Teknologi Perkantoran. Pada kompetensi dasar ini siswa akan diajarkan mengetik dengan terampil. Kegiatan mengetik merupakan kegiatan rutin dan menjadi rutinitas yang dilakukan oleh siswa program keahlian Otomatisasi dan Tata Kelola Perkantoran, sehingga keterampilan mengetik 10 jari perlu dipelajari agar siswa di program keahlian ini dapat mahir dan terampil dalam mengetik 10 jari. Sebagaimana dipaparkan oleh Setyaningsih \& Muhsin [18] bahwa berbagai dunia kerja saat ini menuntut pekerjanya untuk terampil mengetik 10 jari, maka keterampilan ini dapat menjadi nilai tambah bagi siswa. Bahkan dalam dunia perkantoran keterampilan mengetik menjadi faktor penting tercapainya tujuan pekerjaan yang hendak dicapai. Hal senada juga disampaikan oleh Sulastri [21] yang menjelaskan bahwa terdapat 2 asas dalam mengetik sepuluh jari dengan sistem buta (blind system). Yakni aturan jari ketika mengetik dan mengetik tidak melihat tuts.

Ketepatan metode pembelajaran yang digunakan menjadi faktor penting keberhasilan penguasaan keterampilan mengetik 10 jari. Hal senada dipaparkan oleh
Samsudin \& Rahman [17] yang menyatakan bahwa proses belajar dan tujuan belajar mampu diraih dengan menggunakan metode pembelajaran yang bisa membentuk cara-cara pembelajaran yang baik. Metode pembelajaran merupakan taraf yang digunakan oleh pendidik kepada peserta didiknya untuk berinteraksi agar tercapai destinasi pembelajaran yang sudah ditetapkan sesuai dengan mekanisme metode pembelajaran dan materi yang digunakan [1]. Berdasarkan studi pendahuluan tersebut, pemberian metode pembelajaran oleh guru pada kegiatan mengetik 10 jari terhadap siswa tidak dilakukan secara terus-menerus, hanya dilakukan latihan di sekolah pada saat jam pelajaran saja. Hal ini mengakibatkan aktivitas dan keterampilan siswa dalam mengetik masih kurang maksimal. Padahal aktivitas dan keterampilan siswa dapat ditingkatkan dengan melakukan latihan secara terus-menerus, kegiatan ini juga membuat siswa bersemangat dan antusias dalam kegiatan mengetik.

Salah satu perkara yang wajib diperhatikan guru dalam mencapai tujuan pembelajaran yaitu keefektifan metode pembelajaran yang digunakan. Maka, metode pembelajaran drill merupakan metode yang sinkron untuk memberikan peningkatan keterampilan mengetik 10 jari melalui typing master. Metode pembelajaran drill bermanfaat untuk siswa, karena dengan pemberian pemahaman yang bertingkat oleh guru, materi yang diberikan dapat melekat pada diri siswa. Susilowati, Santoso, \& Hamidi [23] menyatakan bahwa drill dapat meningkatkan rasa percaya diri karena dengan latihan, pemahaman yang didapatkan oleh siswa tersimpan dengan baik, sehingga siswa lebih cepat memahami materi.

Penerapan metode drill yang dilakukan peneliti di saat masa pandemi tentu berbeda dengan penerapan metode drill pada saat pembelajaran di keadaan normal. Pada saat pandemi, peneliti menerapkan metode drill melalui typing master dengan pembatasan satu komputer satu siswa, siswa melakukan latihan dengan jaga jarak. Metode ini dilakukan secara individu sehingga dapat mengurangi interaksi siswa dengan siswa yang lain. Metode pembelajaran drill sangat cocok diterapkan pada kompetensi dasar Menerapkan Pengetikan (Keyboarding) 10 Jari Kecepatan 200 EPM dan Ketepatan 99\%, karena belajar mengetik 10 jari pada dasarnya merupakan kompetensi dasar yang membutuhkan keterampilan dan penguasaan tuts pada keyboard. Penguasaan tuts pada keyboard sesuai dengan tomboltombol yang telah ditentukan memerlukan latihan dan pengulangan. Sehingga dengan latihan, siswa mampu meningkatkan keterampilan mengetiknya. Hal ini senada dengan pernyataan Susanti \& Pramusinto [22] yang menyatakan bahwa metode pembelajaran drill yang digunakan dapat membuat siswa melakukan tutorial dan drill mengetik secara rutin dengan menggunakan aplikasi typing master.

Berlandaskan pada kondisi tersebut, maka penelitian ini dimaksudkan untuk meningkatkan aktivitas siswa dan keterampilan mengetik 10 jari siswa kelas X OTKP 1 dengan menerapkan metode pembelajaran drill melalui typing master pada mata pelajaran Teknologi Perkantoran.

\section{KAJIAN TEORI}

Metode Pembelajaran Drill dan Aktivitas Siswa 
Rusman [15] menjelaskan bahwa metode pembelajaran drill adalah bentuk metode pembelajaran yang dilakukan dengan cara memberikan objek sebagai bahan latihan terhadap siswa tentang materi yang sudah diberikan. Sedangkan menurut Hadi [6], metode drill berpengaruh terhadapat ketelitian siswa dalam menyelesaikan masalah secara cepat, tepat, dan lengkap. Metode drill menyiratkan tentang pengulangan sesuatu, sehingga seseorang akan mencoba mengulang-ulang untuk melatih keterampilannya. Metode ini dapat mengaktifkan siswa saat pembelajaran berlangsung karena siswa berusaha mengevaluasi latihanlatihan yang diberikan oleh guru [12]

Berdasarkan pendapat Djamarah \& Zain [4], Urutan pelaksanaan metode drill, yaitu: 1) Fase pemberian latihan. Latihan yang diberikan hendaknya mempertimbangkan kemampuan setiap siswa. Karena kemampuan siswa satu dengan yang lainnya berbeda. Pertimbangan ini dievaluasi agar keterampilan dan kemampuan yang menjadi destinasi guru dapat capai tanpa membebani sisw; 2) Fase pelaksanaan latihan. Latihan yang dilaksanakan harus memenuhi aturan-aturan yang telah dibuat oleh guru, serta menindak jika terjadi pelanggaran. Hal semacam ini perlu dilakukan agar proses latihan berjalan dengan baik dan dapat memberikan kepuasan di akhir latihan baik guru maupun siswa. Namun dengan tidak terlepas dari motivasi guru terhadap siswa; 3) Fase mempertanggungjawabkan latihan. Fase ini memuat intropeksi pembelajaran mulai dari fase pertama. Guru berusaha mengintropeksi kegiatan pembelajarannya serta mengatasinya.

Menurut Vellayati [27], aktivitas siswa merupakan pemberian kesempatan terhadap siswa untuk belajar memahami pelajaran yang diajarkan. Sedangkan menurut Hasmiati, Jamilah, \& Mustami [7] aktivitas siswa merupakan rangkaian kegiatan dalam memperoleh ilmu, memperbaiki perilaku dan mengasah keterampilan sebagai pemberian bekal agar nilai maupun keterampilan siswa dapat berkembang. Selain itu, aktivitas siswa juga dikenal sebagai kesan yang dibuat antara guru dan siswa untuk pembentukan memori jangka panjang dalam proses pembelajaran. Adanya aktivitas yang dilakukan oleh siswa dapat menjadi proses berharga dalam diri siswa untuk mencapai skor atau nilai yang diinginkan. Sehingga partisipasi atau aktivitas siswa dalam kegiatan pembelajaran akan berdampak pada retensi materi yang dipelajari serta mampu menumbuhkan kompetensi dan perkembangan pengetahuan [5].

\section{Keterampilan Mengetik 10 jari dan Typing Master}

Keterampilan yaitu kompetensi yang dibutuhkan dalam penggunanan gagasan, inovasi, dan kreatifitas sebagai bentuk perubahan dalam melakukan atau menciptakan suatu hal agar lebih bernilai sehingga dapat menghasilkan pekerjaan yang bermanfaat [25]. Seseorang dikatakan terampil dalam setiap pekerjaan jika ia melalukan banyak latihan dan terbiasa dengan pekerjaannya. Hal ini juga diperkuat oleh pernyataan dari Ariyatni, [2] yang menyatakan bahwa dengan banyak melakukan latihan dan praktik, maka keterampilan dapat dikuasai dengan baik oleh seseorang. Berdasarkan Peraturan Kemendikbud RI, (2015) Nomor 53 Pasal 8 [9] menyebutkan bahwa indikator keterampilan yang dijadikan penilaian dilakukan melalui praktik, produk, proyek, portofolio, dan/atau teknik lain sesuai dengan kompetensi yang dinilai.

Mengetik merupakan kegiatan yang dilakukan menggunakan teknologi mesin ketik, namun saat ini kegiatan ini biasa dilakukan menggunakan keyboard. Karena mesin ketik sudah jarang digunakan dan diganti dengan mesin yang lebih canggih. Menurut Sulastri [21], dalam istilah Inggris, pengetikan menggunakan sepuluh jari dikenal dengan touch typing, yang mempunyai makna mengetik tidak melihat tuts keyboard yang akan ditulis. Lebih jelasnya bahwa pengetik menggunakan memori otot (muscle memory) untuk mengetahui letak tus keyboard secara tidak langsung. Pembiasaan keterampilan motorik awalnya dimulai dengan mengandalkan kognisi dan penglihatan untuk mempengaruhi kinerja motorik, yang akhirnya mengarah ke otot motorik dan koreksi diri untuk meningkatkan presisi [20].

Keterampilan mengetik 10 jari sangat memerlukan latihan yang dilakukan secara rutin. Jika mengetik 10 jari sudah menjadi rutinitas, maka pengetik dapat dengan sangat terampil mengetik 10 jari dengan cepat dan tepat. [22]. Maka, di era saat ini keterampilan mengetik dibutuhkan oleh seorang sekretaris atau pegawai administrasi, dalam duna bisnis atau perkantoran, seperti perhotelan, travel, Perseroan Terbatas, Firma dan instansi pemerintah seperti pendidikan [8].

Menurut Mariskha, Alhadi, \& Andriyani [10] menyatakan bahwa aplikasi typing master ini adalah perangkat lunak yang memudahkan serta membantu pengetik untuk melakukan latihan mengetik 10 jari. Pada tahap awal, pengetik dapat melakukan latihan huruf secara urut dari A-Z, angka, serta tanda baca dengan dilengkapi gambar posisi jari yang benar. Ketika selesai mengetik, aplikasi ini dapat memuneulkan kecepatan, ketepatan, dan waktu. Sehingga pengetik dapat mengevaluasi kekurangan dirinya ketika mengetik. Tiga pengukuran yang dihasilkan oleh aplikasi typing master diantaranya: WPM kotor, persentase akurasi, WPM bersih. WPM kotor mewakili jumlah kunci WPM terlepas dari kesalahan, persentase akurasi adalah persentase kata yang diketik dengan benar dari semua kata yang dimasukkan, WPM bersih adalah jumlah kata yang benar yang dimasukkan permenit dan digunakan untuk analisis [3].

\section{Metode Penelitian}

\section{Jenis Penelitian}

Penelitian ini adalah jenis Penelitian Tindakan Kelas atau Classroom Action Research. Penelitian tindakan Kelas adalah suatu kegiatan penelitian yang terpaku pada kelas untuk menyelesaikan beberapa permasalahan yang timbul dan yang harus diselesaikan oleh guru, sehingga guru harus mampu melaksanakan penelitian tindakan kelas untuk memberikan kontribusi terhadap perubahan hasil belajar serta perbaikan mutu pendidikan [19].

\section{Prosedur Penelitian}

Subjek dalam penelitian ini sebanayak 22 siswa kelas OTKP 1. Secara umum, Penelitian Tindakan Kelas disebut juga penelitian bersiklus, dengan prosedur tindakan meliputi perencanaan, pelaksanaan, pengamatan, dan refleksi [19]. 1) Tahap perencanaan. Pada tahap perencanaan, peneliti merencanakan proses pembelajaran yang akan dilakukan. 
Diantaranya menentukan topik pembahasan yang akan diberikan, menyiapkan lembar aktivitas siswa, membuat lembar pengamatan keterampilan mengetik 10 jari, dan membuat teks yang akan dijadikan tes keterampilan. 2) Tahap pelaksanaan. Secara garis besar pada tahap pelaksanaan ini berisi sintak mengenai metode pembelajaran yang digunakan, antara lain: a) fase pemberian latihan, jadi dalam fase ini peneliti menjelaskan latihan mengetik yang terdapat di aplikasi typing master, dan memberikan batas waktu latihan; b) fase pelaksanaan latihan, pada fase ini siswa mulai latihan mengetik menggunakan aplikasi typing master dengan batas waktu yang sudah ditentukan oleh peneliti; c) fase mempertanggungjawabkan latihan, dalam fase ini memuat intropeksi dari kegiatan latihan siswa, seperti kedisiplinan dalam mengetik. 3) Tahap pengamatan, ditahap ini peneliti melakukan evaluasi data yang sudah didapatkan untuk diolah, yaitu aktivitas siswa, dan keterampilan mengetik 10 jari diantaranya kecepatan KPM (Karakter Per Menit) dan ketepatan (accuracy) yang dihasilkan dengan menerapkan metode pembelajaran drill. 4) Tahap refleksi, hasil pengamatan yang telah dilaksanakan kemudian dianalisis oleh peneliti untuk dijadikan acuan atau perbaikan pada proses pembelajaran di siklus berikutnya. Adapun kegiatan yang dilaksanakan pada refleksi adalah memperbaiki pelaksanaan pembelajaran dan melakukan pencatatan atas gangguan atau hambatan yang terjadi selama berlangsungnya proses pembelajaran. Instrumen yang digunakan oleh peneliti, antara lain: 1) lembar aktivitas siswa yaitu lembar yang berisi aspek-aspek aktivitas siswa yang perlu diamati; 2) lembar pengamatan keterampilan mengetik 10 jari adalah lembar yang berisi aspek-aspek keterampilan mengetik yang diamati oleh peneliti.

\section{Analisis Hasil Penelitian}

Analisis hasil pada penelitian ini mencakup: 1) Analisis aktivitas siswa, analisis ini diambil berdasarkan sintak dari metode pembelajaran drill. Sintak metode pembelajaran drill yang diterapkan berdasarkan pendapat Djamarah \& Zain [4] yang menyatakan bahwa langkah-langkah metode pembelajaran drill, antara lain: a) fase pemberian latihan, meliputi: antusias siswa di awal pembelajaran, siswa mendengarkan penjelasan dan arahan dari guru, dan kesiapan siswa dalam memulai latihan; b) fase pelaksanaan latihan, meliputi: sikap duduk dalam mengetik, pandangan mata ketika mengetik, peletakan 10 jari sesuai dengan tuts keyboard, dan sikap tenang dan tidak tegang ketika mengetik; c) fase mempertanggungjawabkan latihan, meliputi: bersikap kondusif ketika selesai mengetik, dan menyampaikan kendala ketika mengetik. Kriteria skor pada hasil analisis aktivitas siswa antara lain: 4 (sangat baik), 3 (baik), 2 (cukup baik), 1 (kurang baik). 2) Analisis keterampilan mengetik 10 jari diambil berdasarkan Kemendikbud RI (2015) [9] yang menyatakan bahwa "Indikator keterampilan yang dijadikan penilaian dilakukan melalui praktik, produk, proyek, portofolio, dan/atau teknik lain sesuai dengan kompetensi yang dinilai". Kriteria skor pada hasil keterampilan mengetik 10 jari pada aspek kecepatan KPM (Karakter Per Menit) disajikan sebagai berikut: 151-200 (sangat baik), 101-150 (baik), 51-100 (cukup baik), 1-50 (kurang baik). Sedangkan kriteria persentase pada hasil keterampilan mengetik 10 jari pada aspek ketepatan (accuracy) antara lain: 76-100 (sangat baik), 51-75 (baik), 26-50 (cukup baik), 1-25 (kurang baik).

\section{Hasil dan Pembahasan}

Aktivitas Siswa dan Keterampilan Mengetik 10 Jari
Siswa Kelas X OTKP 1 pada Saat Penerapan Metode
Pembelajaran Drill melalui Typing Master pada Mata
Pelajaran Teknologi Perkantoran

Data yang didapatkan oleh peneliti adalah data aktivitas pada saat pembelajaran luring yang berlangsung di sekolah dengan kelas X OTKP 1. Aktivitas dan keterampilan mengetik 10 jari siswa kelas X OTKP 1 pada saat penerapan metode pembelajaran drill melalui typing master pada mata pelajaran Teknologi Perkantoran dilakukan sebanyak tiga siklus dan tiap siklusnya dilaksanakan dalam satu kali tatap muka. Untuk pemaparan disetiap siklusnya dijabarkan sebagai berikut.

\section{Siklus I}

Pelaksanaan pembelajaran di siklus I, dijelaskan berikut ini:

Pertama adalah tahap perencanaan. Di tahap ini perlu dipersiapkan segala hal yang berkaitan dengan pelaksanaan pembelajaran, diantaranya: 1) mempersiapkan topik bahasan yang akan diberikan, yaitu pokok kegiatan mengetik 10 jari seperti mengenalkan tuts keyboard, sikap duduk, dan sikap tubuh yang benar ketika mengetik, serta pandangan mata; mempersiapkan media bantu yang digunakan dalam penyampaian pokok bahasan yaitu laptop, LCD, dan powerpoint; menyiapkan pretest dan posttest dalam bentuk naskah surat; 2) menyiapkan lembar aktivitas siswa dan lembar pengamatan keterampilan mengetik 10 jari.

Kedua adalah tahap pelaksanaan yang terdiri dari tiga tahapan, yaitu: 1) Tahap awal. Tahap ini dimulai dengan pemberian sapaan oleh guru; melakukan presensi kehadiran siswa; mengkondisikan kelas agar kelas kondusif dan siswa siap untuk melakukan latihan; memastikan siswa telah membuka komputernya masing-masing; guru memberikan informasi terhadap siswa mengenai peraturan yang perlu ditaati pada saat pembelajaran serta memberitahukan manfaat yang diperoleh siswa ketika menggunakan metode pembelajaran drill dalam mengetik 10 jari; 2) Tahap inti. Kegiatan inti dimulai dengan guru memberikan pretest kepada siswa; setelah selesai, guru memberikan pengantar sedikit terkait materi dasar mengetik 10 jari yang ditampilkan melalui media power point; guru meminta siswa untuk membuka aplikasi typing master pada masing-masing komputer; guru memberikan arahan kepada siswa untuk login dengan nama lengkap dan nomor presensi; guru memberikan penjelasan sedikit mengenai beberapa menu yang terdapat pada aplikasi typing master; setelah itu guru mulai memberikan latihan dasar, latihan yang diberikan pada siklus I adalah latihan yang ada di menu Touch Typing Test yakni latihan huruf-huruf; latihan yang diberikan kepada siswa yaitu lesson 1-6 dengan masing-masing waktu yang diberikan adalah tiga menit; siswa mulai latihan mengetik; di tengah-tengah latihan, guru memberikan waktu istirahat sebentar agar siswa tidak cepat lelah dalam mengetik; setiap selesai latihan mengetik di tiap lesson, siswa dapat langsung melihat hasil yang didapatkan; setelah selesai latihan lesson 1-6, guru memberikan posttest berupa naskah surat; guru 
membahas hasil latihan mengetik siswa; tidak lupa juga siswa diberikan kesempatan untuk menyampaikan kendala selama latihan berlangsung; 3) Tahap penutup. Di tahap penutup guru maupun siswa menyimpulkan pembelajaran yang telah berlangsung; setelah memberikan kesimpulan, guru memberikan tugas latihan di rumah meneruskan lesson 7-8 pada menu Touch Typing Test dan memberikan batas waktu 3 menit; hasil dari latihan discreenshot dan disimpan; guru akan membahas hasil latihan di pertemuan berikutnya; siswa mematikan komputer masing-masing; setelah itu guru mengakhiri pembelajaran dengan memberikan salam.

Ketiga adalah pengamatan. Pengamatan dilaksanakan pada saat berlangsungnya pembelajaran. Hasil dari pengamatan aktivitas siswa dan keterampilan mengetik 10 jari pada siklus I disajikan pada tabel 1 dan tabel 2 berikut ini:

Tabel 1. Hasil Analisis Aktivitas Siswa Siklus I

\begin{tabular}{|c|c|c|c|c|c|c|}
\hline \multirow[t]{2}{*}{ No } & \multirow{2}{*}{\multicolumn{2}{|c|}{ Aspek yang Diamati }} & \multicolumn{2}{|c|}{ Skor } & \multirow{2}{*}{$\begin{array}{l}\text { Rata } \\
\text {-rata }\end{array}$} & \multirow[t]{2}{*}{ Kriteria } \\
\hline & & & P1 & $\mathrm{P} 2$ & & \\
\hline \multirow{4}{*}{1} & \multicolumn{6}{|c|}{ Fase pemberian latihan } \\
\hline & \multicolumn{2}{|c|}{$\begin{array}{l}\text { a. antusias di awal } \\
\text { pembelajaran }\end{array}$} & & & & \\
\hline & \multicolumn{2}{|c|}{$\begin{array}{l}\text { b. mendengarkan } \\
\text { penjelasan dan arahan dari } \\
\text { guru }\end{array}$} & & & & \\
\hline & \multicolumn{2}{|c|}{$\begin{array}{l}\text { c. kesiapan dalam memulai } \\
\text { latihan }\end{array}$} & & & & $\begin{array}{l}\text { Cukt } \\
\text { baik }\end{array}$ \\
\hline \multirow{5}{*}{2} & \multicolumn{6}{|c|}{ Fase pelaksanaan latihan } \\
\hline & \multicolumn{2}{|c|}{$\begin{array}{l}\text { a. Sikap duduk dalam } \\
\text { mengetik }\end{array}$} & 2 & & & \\
\hline & \multicolumn{2}{|c|}{$\begin{array}{l}\text { b. pandangan mata ketika } \\
\text { mengetik }\end{array}$} & 1 & & & \\
\hline & \multicolumn{2}{|c|}{$\begin{array}{l}\text { c. peletakan } 10 \text { jari sesuai } \\
\text { dengan tuts keyboard }\end{array}$} & 2 & 2 & & Cuku \\
\hline & \multicolumn{2}{|c|}{$\begin{array}{l}\text { d. sikap tenang dan tidak } \\
\text { tegang ketika mengetik }\end{array}$} & 2 & 2 & & $\begin{array}{l}\text { Cukup } \\
\text { baik }\end{array}$ \\
\hline \multirow{3}{*}{3} & \multicolumn{6}{|c|}{ Fase Mempertanggungjawabkan Latihan } \\
\hline & \multicolumn{2}{|c|}{$\begin{array}{l}\text { a. bersikap kondusif ketika } \\
\text { selesai mengetik }\end{array}$} & 2 & 2 & & $\begin{array}{l}\text { Cukup } \\
\text { baik }\end{array}$ \\
\hline & \multicolumn{2}{|c|}{$\begin{array}{l}\text { b. menyampaikan kendala } \\
\text { ketika mengetik }\end{array}$} & 3 & 2 & 2,5 & $\begin{array}{l}\text { Cukup } \\
\text { baik }\end{array}$ \\
\hline \multicolumn{3}{|c|}{ Rata-rata } & 2 & $\begin{array}{c}1,7 \\
8\end{array}$ & 1,89 & $\begin{array}{l}\text { Kurang } \\
\text { baik }\end{array}$ \\
\hline & & & Sum & er: D & ita Di & olah 2021 \\
\hline \multicolumn{7}{|c|}{$\begin{array}{l}\text { Tabel 2. Hasil Analisis Keterampilan } \\
\text { Siklus I }\end{array}$} \\
\hline \multirow[t]{2}{*}{ No } & \multirow[t]{2}{*}{ Indikator } & \multirow{2}{*}{$\begin{array}{l}\text { Aspek yang } \\
\text { diamati }\end{array}$} & \multicolumn{2}{|c|}{ Skor } & \multirow{2}{*}{$\begin{array}{l}\text { Rata } \\
\text {-rata }\end{array}$} & \multirow[t]{2}{*}{ Kriteria } \\
\hline & & & $\mathrm{P} 1$ & $\mathrm{P} 2$ & & \\
\hline 1 & Praktik & $\begin{array}{l}\text { Kecepatan KPM } \\
\text { (Karakter Per } \\
\text { Menit) yang } \\
\text { diperoleh }\end{array}$ & 61 & 61 & 61 & $\begin{array}{l}\text { Cukup } \\
\text { baik }\end{array}$ \\
\hline
\end{tabular}

\begin{tabular}{|l|l|l|l|l|l|l|}
\hline 2 & Praktik & $\begin{array}{l}\text { Ketepatan } \\
\text { (Accuracy) } \\
\text { Persentase } \\
\text { Ketepatan yang } \\
\text { diperoleh }\end{array}$ & 49 & 49 & 49 & $\begin{array}{l}\text { Cukup } \\
\text { baik }\end{array}$ \\
\hline
\end{tabular}

Sumber: Data Diolah 2021

Berdasarkan tabel 1 tersebut, didapati bahwa hasil analisis aktivitas siswa di siklus I secara keseluruhan mendapat rata-rata skor sebesar 1,89 dengan kriteria kurang baik. Hal ini dilihat pada aspek berikut: 1) antusias di awal pembelajaran memperoleh skor 1,5 (kurang baik). Berdasarkan hasil pengamatan pada saat akan melakukan pembelajaran, antusias siswa sangat penting untuk menumbuhkan semangat belajar. Pada pelaksanaan pembelajaran di siklus I, terdapat siswa yang terlambat, artinya mereka kurang antusias saat akan melakukan pembelajaran mengetik. Ini terjadi karena siswa belum mengetahui tenik yang harus mereka lakukan saat pembelajaran. Senada dengan penelitian yang dilaksanakan oleh Hadi [6] bahwa di pertemuan pertama perubahan sikap dalam diri siswa masih kurang maksimal karena rasa ingin tahu dan minat siswa belum dikembangkan, sehingga motivasi belajarnya rendah; 2) mendengarkan penjelasan dan arahan dari guru memperoleh skor 2 (cukup baik). Karena sebagian siswa tidak mendengarkan penjelasan dan arahan dari guru dan siswa lebih banyak mengobrol dengan teman; 3) kesiapan dalam memulai latihan memperoleh skor 2 (cukup baik). Berdasarkan hasil pengamatan, siswa masih sibuk mengerjakan tugas mata pelajaran lain sehingga masih ada siswa yang belum menyalakan komputer masing-masing; 4) sikap duduk dalam mengetik, selama proses mengetik dengan sistem 10 jari, cara duduk siswa yang baik dan benar, yaitu duduk/urus di depan mesin ketik dengan badan tegap dan bersandar pada sandaran kursi [28]. Aspek ini memperoleh skor 2 (cukup baik); 5) pandangan mata ketika mengetik memperoleh skor 1 (kurang baik). Pandangan mata yang benar saat mengetik yaitu tertuju ke arah layar monitor, akan tetapi hampir semua siswa pandangan matanya masih ke arah tuts keyboard; 6) peletakan 10 jari sesuai dengan tuts keyboard memperoleh skor 2 (cukup baik). Pada saat latihan, masih terdapat siswa yang tidak meletakkan 10 jarinya dengan benar, siswa yang tidak menerapkan peletakan jari dengan benar pada umumnya menggunakan 2 jari telunjuk, 4 jari, 6 jari, dan 8 jari. Siswa yang menggunakan 6 jari hanya menggunakan jari tengah, jari telunjuk dan ibu jari. Sedangkan penggunaan 8 jari menggunakan jari manis, jari tengah, jari telunjuk dan ibu jari [28]; 7) sikap tenang dan tidak tegang ketika mengetik memperoleh skor 2 (cukup baik). Sikap ini perlu diimplementasikan ketika sedang mengetik, karena jika pengetik terlalu tegang maka akan cepat lelah. Pada siklus I sebgaian besar siswa merasa bingung dengan penjelasan atau aturan yang sudah dijelaskan jadi masih terdapat siswa yang saling bertanya terhadap temannya. Hal ini senada dengan hasil penelitian dari Susanti \& Pramusinto [22] bahwa pada siklus I saat mengetik surat siswa masih bingung dengan bentuk indented padahal sudah dijelaskan sehingga masih ada yang menengok pekerjaan teman di sebelahnya; 8) bersikap kondusif ketika selesai mengetik memperoleh skor 2 (cukup baik). Sikap ini perlu diimplementasikan agar 
ketika selesai mengetik kondisi kelas tetap kondusif; 9) menyampaikan kendala saat mengetik memperoleh skor 2,5 (cukup baik). Aspek ini adalah aspek terakhir yang harus dilakukan agar kendala atau gangguan yang dialami siswa selama pembelajaran berlangsung dapat diketahui oleh guru. Aspek yang dinilai adalah bahasa yang sopan dan baik ketika sedang menyampaikan kendala. Dari semua aspek tersebut, dapat dinyatakan bahwa pada siklus I ini perlu dilakukan perbaikan dengan cara mengatasi kendala yang terjadi di siklus berikutnya. Hal ini senada dengan hasil penelitian yang dipaparkan oleh Ariyatni [2] bahwa pada siklus pertama, terdapat kendala yang dialami peserta didik, sehingga guru perlu mendesain model pembelajaran yang lebih sempurna lagi dengan cara mencermati segala indikator pendukung dengan merancang pembelajaran.

Berdasarkan Tabel 2 tersebut, pada siklus I didapati bahwa hasil analisis keterampilan mengetik 10 jari pada aspek kecepatan KPM (Karakter Per Menit) secara keseluruhan mendapat rata-rata skor sejumlah 61 termasuk dalam kriteria cukup baik. Sedangkan hasil analisis keterampilan mengetik 10 jari pada aspek ketepatan (accuracy) secara keseluruhan mendapat rata-rata persentase sejumlah $49 \%$ termasuk dalam kriteria cukup baik. Pada siklus I keterampilan mengetik 10 jari siswa belum maksimal karena siswa jarang latihan mengetik sehingga siswa belum terbiasa dengan mengetik 10 jari, dan masih ada siswa yang sama sekali belum disiplin dalam mengetik. Pernyataan ini didukung oleh Susanti \& Pramusinto [22] yang hasil penelitiannya menunjukkan bahwa pada siklus I pada saat dilihat dari aspek penerapan 10 jari saat mengetik menunjukkan bahwa masih terdapat siswa yang sama sekali belum disiplin dalam menerapkan 10 jari, hal ini dikarenakan siswa baru diajarkan mengetik 10 jari dengan mengetik naskah surat. Hasil penelitian yang sama juga dilakukan oleh Rozi, Indrawati, \& Widodo [14] yang hasil penelitiannya menyatakan bahwa hasil analisis keterampilan mengetik di siklus pertama belum tercapai, karena total siswa yang memeroleh skor di atas KKM tidak mencapai $70 \%$.

Keempat adalah tahap refleksi. Tahap ini dilakukan setelah tahap pelaksanaan dan tahap pengamatan selesai. Di tahap terakhir dari siklus I ini guru melakukan intropeksi dan menelaah kekurangan-kekurangan untuk selanjutnya dilakukan perbaikan di siklus II. Berikut ini adalah refleksi dari siklus I: 1) guru sebaiknya lebih memotivasi siswa di awal pembelajaran maupun saat pembelajaran drill berlangsung, dengan cara lebih mendekati siswa dan memberikan arahan-arahan yang mudah dimengerti oleh siswa; 2) guru sebaiknya bersikap tegas atas kecurangan yang mungkin dilakukan oleh siswa pada saat latihan mengetik 10 jari.

\section{Siklus II}

Pelaksanaan pembelajaran di siklus II, dijelaskan berikut ini: Pertama adalah tahap perencanaan. Di tahap ini perlu dipersiapkan segala hal yang berkaitan dengan pelaksanaan pembelajaran, diantaranya: menyiapkan topik bahasan yang akan diberikan, yakni topik bahasan tentang mengetik teks prosedur. Dalam pengetikan teks prosedur siswa perlu menyisipkan nomor; menyiapkan komputer sebagai media yang digunakan untuk latihan; mempersiapkan pretest dan posttest berupa naskah teks prosedur; menyiapkan lembar aktivitas siswa dan lembar pengamatan keterampilan mengetik 10 jari.

Kedua adalah tahap pelaksanaan yang terdiri dari tiga tahapan, yaitu: 1) Tahap awal. Tahap ini dimulai dengan pemberian sapaan oleh guru; melakukan presensi kehadiran siswa; mengkondisikan kelas agar kelas menjadi kondusif dan siswa siap untuk melakukan latihan; memastikan siswa telah membuka komputernya masing-masing; guru menjelaskan prosedur dalam metode pembelajaran drill beserta manfaatnya; guru menyampaikan tujuan pembelajaran dan melakukan review ulang mengenai materi sebelumnya dan tugas latihan mengetik di siklus I serta menanyakan kendala yang dialami siswa selama latihan di rumah; 2) Tahap inti. Kegiatan inti dimulai dengan memberikan pretest kepada siswa; setelah itu guru memberikan pengantar sedikit tentang mengetik teks prosedur; selanjutnya peneliti meminta siswa untuk membuka aplikasi typing master di komputer masing-masing dan siswa langsung login; setelah itu guru memberikan latihan mengetik dengan meneruskan lesson pada menu Touch Typing Test; siswa memulai latihan lesson 9-12 dengan waktu yang diberikan masing-masing lesson adalah tiga menit; di tengah-tengah latihan, guru memberikan games yang terdapat pada aplikasi typing master, selain itu guru juga memberikan waktu istirahat agar siswa tidak merasa cepat lelah dalam mengetik; setiap selesai mengetik di tiap lesson, siswa dapat langsung melihat hasil yang diperoleh; setelah selesai latihan lesson 9-12, guru memberikan postest berupa teks prosedur; guru membahas hasil latihan mengetik siswa; tidak lupa juga siswa diberikan kesempatan untuk menyampaikan kendala selama latihan berlangsung; 3) Tahap penutup. Di tahap penutup, guru maupun siswa menyimpulkan pembelajaran yang telah berlangsung; setelah memberikan kesimpulan, guru memberikan tugas latihan di rumah, tugas yang diberikan terdapat pada menu course, lalu speed building course lesson 1-2 dan diberikan batas waktu latihan selama 3 menit; hasil dari latihan discreenshoot dan disimpan; guru akan membahas hasil latihan di siklus selanjutnya; siswa mematikan komputer masing-masing; setelah itu guru memberikan salam di akhir pembelajaran.

Ketiga adalah pengamatan. Pengamatan dilaksanakan pada saat berlangsungnya pembelajaran. Hasil dari pengamatan aktivitas siswa dan keterampilan mengetik 10 jari pada siklus II disajikan pada Tabel 3 dan Tabel 4 berikut ini:

Tabel 3. Hasil Analisis Aktivitas Siswa Siklus II

\begin{tabular}{|c|l|c|c|c|c|} 
No & \multicolumn{1}{|c|}{ Aspek yang Diamati } & \multicolumn{2}{|c|}{ Skor } & Rata & Kriteria \\
\cline { 3 - 6 } & P1 & P2 & -rata & \\
\hline \multirow{2}{*}{1} & Fase pemberian latihan & \multicolumn{3}{|l|}{} \\
\cline { 2 - 6 } & $\begin{array}{l}\text { a. antusias di awal } \\
\text { pembelajaran }\end{array}$ & 3 & 3 & 3 & Baik \\
\hline $\begin{array}{l}\text { b. mendengarkan } \\
\text { penjelasan dan arahan dari } \\
\text { guru }\end{array}$ & 3 & 3 & 3 & Baik \\
\hline & c. kesiapan dalam memulai & 2 & 3 & 2,5 & Cukup \\
\hline
\end{tabular}




\begin{tabular}{|c|c|c|c|c|c|}
\hline & latihan & & & & baik \\
\hline \multirow{5}{*}{2} & \multicolumn{5}{|l|}{ Fase pelaksanaan latihan } \\
\hline & $\begin{array}{l}\text { a. Sikap duduk dalam } \\
\text { mengetik }\end{array}$ & 3 & 3 & 3 & Baik \\
\hline & $\begin{array}{l}\text { b. pandangan mata ketika } \\
\text { mengetik }\end{array}$ & 2 & 2 & 2 & $\begin{array}{l}\text { Cukup } \\
\text { baik }\end{array}$ \\
\hline & $\begin{array}{l}\text { c. peletakan } 10 \text { jari sesuai } \\
\text { dengan tuts keyboard }\end{array}$ & 2 & 3 & 2,5 & $\begin{array}{l}\text { Cukup } \\
\text { baik }\end{array}$ \\
\hline & $\begin{array}{l}\text { d. sikap tenang dan tidak } \\
\text { tegang ketika mengetik }\end{array}$ & 3 & 3 & 3 & Baik \\
\hline \multirow{3}{*}{3} & \multicolumn{5}{|c|}{ Fase Mempertanggungjawabkan Latihan } \\
\hline & $\begin{array}{l}\text { a. bersikap kondusif ketika } \\
\text { selesai mengetik }\end{array}$ & 3 & 3 & 3 & Baik \\
\hline & $\begin{array}{l}\text { b. menyampaikan kendala } \\
\text { ketika mengetik }\end{array}$ & 3 & 3 & 3 & \\
\hline \multicolumn{2}{|c|}{ Rata-rata } & $\begin{array}{l}2,6 \\
7\end{array}$ & 2,8 & & Cukup \\
\hline
\end{tabular}

Sumber: Data Diolah 2021

Tabel 4. Hasil Analisis Keterampilan Mengetik 10 Jari Siklus II

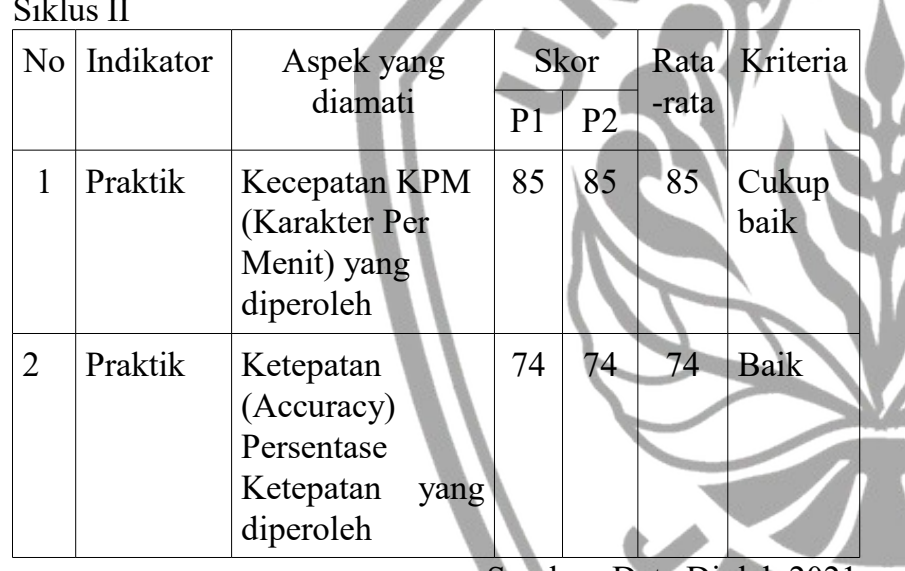

Sumber: Data Diolah 2021

Berdasarkan Tabel 3 tersebut, didapati bahwa aktivitas siswa pada siklus II meningkat jika dibandingakan dengan siklus I. Secara keseluruhan mendapat rata-rata skor sebesar 2,78 termasuk dalam kriteria cukup baik. Aspek yang dinilai, antara lain: 1) antusias di awal pembelajaran memperoleh skor 3 (baik); 2) mendengarkan penjelasan dan arahan dari guru memperoleh skor 3 (baik); 3) kesiapan dalam memulai latihan memperoleh skor 2,5 (cukup baik); 4) sikap duduk dalam mengetik memperoleh skor 3 (baik); 5) pandangan mata ketika mengetik memperoleh skor 2 (cukup baik); 6) peletakan 10 jari sesuai dengan tuts keyboard memperoleh skor 2,5 (cukup baik); 7) sikap tenang dan tidak tegang ketika mengetik memperoleh skor 3 (baik); 8) bersikap kondusif ketika selesai mengetik memperoleh skor 3 (baik); 9) menyampaikan kendala ketika mengetik memperoleh skor 3 (baik). Dari beberapa aspek yang diamati, terdapat aspek yang belum memenuhi kriteria baik, diantaranya: 1) kesiapan dalam memulai latihan, terdapat beberapa siswa yang masih sibuk dengan tugas mata pelajaran lain sehingga terlihat belum siap melakukan pembelajaran; 2) pandangan mata ketika mengetik, sebagian besar siswa ketika mengetik pandangan matanya selalu melihat ke arah keyboard; 3) peletakan 10 jari sesuai dengan tuts keyboard, terdapat siswa yang masih belum menerapkan peletakan 10 jari dengan benar, bahkan masih terdapat siswa yang mengetik menggunakan 6 atau 8 jari. Berdasarkan hasil pengamatan, dapat diperoleh kesimpulan bahwa aktivitas siswa pada siklus II meningkat daripada siklus pertama. Hal tersebut senada dengan penelitian yang dilakukan oleh Syaerozi, Supraptono, \& Sutarno [24] yang hasil penelitiannya menunjukkan bahwa aktivitas siswa di siklus II mengalami peningkatan dari siklus I, sehingga dapat memenuhi pencapaian standar klasikal minimal yang ditentukan oleh peneliti. Berdasarkan wawancara yang dilakukan dengan siswa, siswa mengungkapkan bahwa siswa lebih berantusias daripada siklus I, karena siswa mulai terbiasa dengan mengetik dan melakukannya secara terus-menerus. Pernyataan ini juga didukung oleh Susanti \& Pramusinto [22] yang hasil penelitiannya menunjukkan bahwa jumlah siswa yang terampil mengetik 10 jari mengalami peningkatan karena siswa berlatih secara kontinyu sehingga bertambah cekatan dalam menerapkan sistem 10 jari saat mengetik.

Berdasarkan Tabel 4 tersebut, dapat diketahui bahwa hasil analisis keterampilan mengetik 10 jari pada aspek kecepatan KPM (Karakter Per Menit) siklus II secara keseluruhan mendapat rata-rata skor sejumlah 85 termasuk dalam kriteria cukup baik. Sedangkan hasil analisis keterampilan mengetik 10 jari pada aspek ketepatan (accuracy) secara keseluruhan mendapat rata-rata persentase sejumlah $74 \%$ termasuk dalam kriteria baik. Sehingga dapat dinyatakan bahwa hasil skor keterampilan mengetik 10 jari pada siktus II mengalami peningkatan dari siklus I, tetapi hasil keterampilan pada aspek kecepatan KPM (Karakter Per Menit) masih belum mencapai hasil baik, maka perlu dilakukan siklus III agar peningkatan keterampilan meningkat sesuai dengan standar minimum ketuntasan. Pernyataan ini juga didukung oleh Ninghardjanti \& Yuwantiningsih [11] yang hasil penelitiannya menunjukkan bahwa hasil kecepatan maupun ketepatan di siklus II menunjukkan peningkatan yang signifikan terhadap keterampilan mengetik peserta didik jika dibandingkan dengan tes kecepatan dan keterampilan di siklus I. Diperoleh rata-rata kecepatan meningkat sebesar $88 \mathrm{kpm}$ dan rata-rata ketepatan meningkat sebesar $64 \%$. Namun untuk keterampilan mengetik belum memenuhi ketuntasan secara klasikal karena masih terdapat salah satu aspek yang tidak terpenuhi. Sehingga dari hasil siklus II guru merencakan pelaksanaan pembelajaran yang lebih kompleks pada siklus selanjutnya. Hasil penelitian yang senada dilakukan oleh Setyaningsih \& Muhsin [18] yang hasil penelitiannya menyatakan bahwa hasil pengamatan pada siklus II, rata-rata keterampilan mengetik sistem 10 jari buta siswa meningkat menjadi kategori terampil $(70,2 \%)$ dibanding siklus I dengan kategori cukup terampil $(54,9 \%)$.

Keempat adalah tahap refleksi. Di tahap ini guru melakukan intopeksi dan menelaah kekurangan-kekurangan untuk selanjutnya dilakukan perbaikan di siklus III. Adapun yang harus diperbaiki diantaranya: 1) sebelum pembelajaran dimulai, guru harus memastikan semuanya sudah siap baik 
siswa maupun komputer yang akan digunakan; 2) guru harus bersikap tegas dan memberikan peringatan terhadap siswa yang tidak menaati aturan di awal pembelajaran maupun saat pembelajaran berlangsung; 3) guru lebih melakukan pengamatan yang menyeluruh kepada siswa agar tidak ada siswa yang curang dalam mengetik.

\section{Siklus III}

Pelaksanaan pembelajaran di siklus III, dijelaskan berikut ini:

Pertama adalah tahap perencanaan. Di tahap ini perlu dipersiapkan segala hal yang berkaitan dengan pelaksanaan pembelajaran, diantaranya: menyiapkan topik bahasan yang akan diberikan, yakni topik bahasan tentang mengetik cerita pendek (cerpen). Pembahasan dalam mengetik cerpen adalah menulis lengkap mulai dari huruf, angka, huruf kapital, serta tanda baca yang lengkap; menyiapkan komputer sebagai media yang digunakan untuk latihan; mempersiapkan pretest dan posttest berupa cerita pendek; menyiapkan lembar aktivitas siswa dan lembar pengamatan keterampilan mengetik 10 jari.

Kedua adalah tahap pelaksanaan yang terdiri dari tiga tahapan, yaitu: 1) Tahap awal. Tahap ini dimulai dengan pemberian sapaan oleh guru; melakukan presensi kehadiran siswa; mengkondisikan kelas agar kelas menjadi kondusif dan siswa siap untuk melakukan latihan; memastikan siswa telah membuka komputer masing-masing; guru menjelaskan prosedur dalam metode pembelajaran drill beserta manfaatnya; guru menyampaikan tujuan pembelajaran dan melakukan review ulang materi sebelumnya dan tugas latihan mengetik di siklus II serta menanyakan kendala yang dialami siswa selama latihan di rumah; 2) Tahap inti. Kegiatan inti dimulai dengan memberikan pretest kepada siswa; setelah itu guru memberikan pengantar sedikit tentang mengetik teks cerpen; selanjutnya guru meminta siswa untuk membuka aplikasi typing master di komputer masing-masing siswa dan siswa langsung login; setelah itu guru memberikan latihan mengetik pada menu course lalu speed building test lesson 3-6 dengan waktu yang diberikan masing-masing lesson adalah tiga menit; di tengah-tengah latihan, guru memberikan games yang terdapat pada aplikasi typing master, selain itu guru juga memberikan waktu istirahat agar siswa tidak merasa cepat lelah dalam mengetik; setelah selesai latihan lesson 3-6, guru memberikan posttest kepada siswa; guru membahas hasil mengetik siswa; tidak lupa juga siswa diberikan kesempatan untuk menyampaikan kendala selama latihan berlangsung; 3) Tahap penutup. Di tahap penutup, guru maupun siswa menyatakan kesimpulan pembelajaran yang telah berlangsung; setelah memberikan kesimpulan, guru memberikan tugas latihan di rumah, tugas yang diberikan terdapat pada menu typing test yaitu test text 10-keys test, all keys, 10-key test, numbers only dengan waktu yang diberikan di masing-masing test text adalah 5 menit; hasil latihan discreenshoot dan disimpan; guru akan membahas hasil latihan di pertemuan selanjutnya; siswa mematikan komputer masing-masing; setelah itu guru memberikan salam di akhir pembelajaran.

Ketiga adalah pengamatan. Pengamatan dilaksanakan pada saat berlangsungnya pembelajaran. Hasil dari pengamatan aktivitas siswa dan keterampilan mengetik 10 jari pada siklus III disajikan pada Tabel 5 dan Tabel 6 berikut ini:

Tabel 5. Hasil Analisis Aktivitas Siswa Siklus III

\begin{tabular}{|c|c|c|c|c|c|}
\hline \multirow[t]{2}{*}{ No } & \multirow[t]{2}{*}{ Aspek yang Diamati } & \multicolumn{2}{|c|}{ Skor } & \multirow{2}{*}{$\begin{array}{l}\text { Rata } \\
\text {-rata }\end{array}$} & \multirow[t]{2}{*}{ Kriteria } \\
\hline & & P1 & $\mathrm{P} 2$ & & \\
\hline \multirow{4}{*}{1} & \multicolumn{5}{|l|}{ Fase pemberian latihan } \\
\hline & $\begin{array}{l}\text { a. antusias di awal } \\
\text { pembelajaran }\end{array}$ & 4 & 4 & 4 & $\begin{array}{l}\text { Sangat } \\
\text { Baik }\end{array}$ \\
\hline & $\begin{array}{l}\text { b. mendengarkan } \\
\text { penjelasan dan arahan dari } \\
\text { guru }\end{array}$ & 4 & 4 & 4 & $\begin{array}{l}\text { Sangat } \\
\text { Baik }\end{array}$ \\
\hline & $\begin{array}{l}\text { c. kesiapan dalam memulai } \\
\text { latihan }\end{array}$ & 4 & 4 & 4 & $\begin{array}{l}\text { Sangat } \\
\text { Baik }\end{array}$ \\
\hline
\end{tabular}

Fase pelaksanaan latihan

\begin{tabular}{|l|l|l|l|l|}
\hline a. Sikap duduk dalam & 3 & 3 & 3 & Baik
\end{tabular}
mengetik

b. pandangan mata ketika

2 mengetik

\begin{tabular}{|l|l|l|l|l|}
\hline c. peletakan 10 jari sesuai & 4 & 4 & 4 & Sangat
\end{tabular} \begin{tabular}{l|l|l|} 
dengan tuts keyboard & & Baik
\end{tabular}

\begin{tabular}{|l|l|l|l|l|l|}
\hline d. Sikap tenang dan tidak & 4 & 4 & 4 & Sangat
\end{tabular} tegang ketika mengetik

Baik

Fase Mempertanggungjawabkan Latihan

\begin{tabular}{|l|l|l|l|l|}
\hline a. bersikap kondusif ketika & 3 & 4 & 3,5 & Baik
\end{tabular} selesai mengetik

\begin{tabular}{|l|l|l|l|l|}
\hline b. menyampaikan kendala & 4 & 4 & 4 & Sangat
\end{tabular} ketika mengetik

\begin{tabular}{|l|l|l|l|l|l|}
\hline Rata-rata & $\begin{array}{l}3,6 \\
7\end{array}$ & $\begin{array}{l}3,7 \\
8\end{array}$ & 3,72 & Baik \\
\hline
\end{tabular}

Sumber: Data Diolah 2021

Tabel 6. Hasil Analisis Keterampilan Mengetik 10 Jari

\begin{tabular}{|c|c|c|c|c|c|c|}
\hline \multirow[t]{2}{*}{ No } & \multirow[t]{2}{*}{ Indikator } & \multirow{2}{*}{$\begin{array}{c}\text { Aspek yang } \\
\text { diamati }\end{array}$} & \multicolumn{2}{|c|}{ Skor } & \multirow{2}{*}{$\begin{array}{l}\text { Rata } \\
\text {-rata }\end{array}$} & \multirow[t]{2}{*}{ Kriteria } \\
\hline & & & $\mathrm{P} 1$ & $\mathrm{P} 2$ & & \\
\hline 1 & Praktik & $\begin{array}{l}\text { Kecepatan KPM } \\
\text { (Karakter Per } \\
\text { Menit) yang } \\
\text { diperoleh }\end{array}$ & $\begin{array}{c}11 \\
5\end{array}$ & 115 & 115 & Baik \\
\hline 2 & Praktik & $\begin{array}{l}\text { Ketepatan } \\
\text { (Accuracy) } \\
\text { Persentase } \\
\text { Ketepatan yang } \\
\text { diperoleh }\end{array}$ & 90 & 90 & 90 & $\begin{array}{l}\text { Sangat } \\
\text { Baik }\end{array}$ \\
\hline
\end{tabular}

Sumber: Data Diolah 2021

Berdasarkan Tabel 5 tersebut, didapati bahwa aktivitas siswa pada siklus III secara keseluruhan mendapat rata-rata skor sejumlah 3,72 termasuk dalam kriteria baik. Aspek yang dinilai, antara lain: 1) antusias di awal pembelajaran memperoleh skor 4 (sangat baik); 2) mendengarkan penjelasan dan arahan dari guru memperoleh skor 4 (sangat 
baik); 3) kesiapan dalam memulai latihan memperoleh skor 4 (sangat baik); 4) sikap duduk dalam mengetik memperoleh skor 3 (baik); 5) pandangan mata ketika mengetik memperoleh skor 3 (baik); 6) peletakan 10 jari sesuai dengan tuts keyboard memperoleh skor 4 (sangat baik); 7) sikap tenang dan tidak tegang ketika mengetik memperoleh skor 4 (sangat baik); 8) bersikap kondusif ketika selesai mengetik, memperoleh skor 3,5 (baik); 9) menyampaikan kendala ketika mengetik memperoleh skor 4 (sangat baik). Berdasarkan hasil pengamatan di siklus III, aktivitas siswa meningkat dibandingkan siklus II. Kondisi kelas lebih tenang dan siswa mengerjakan latihan dengan sangat antusias dan terarah. Ketika selesai latihan, siswa kondusif dan tidak ramai, sehingga tidak menganggu siswa lain yang masih belum selesai latihan.

Berdasarkan Tabel 6 tersebut, didapati bahwa hasil analisis keterampilan mengetik 10 jari pada pada aspek kecepatan KPM (Karakter Per Menit) siklus III secara keseluruhan mendapat rata-rata skor sejumlah 115 termasuk dalam kriteria baik. Sedangkan hasil analisis keterampilan mengetik 10 jari pada aspek ketepatan (accuracy) siklus III secara keseluruhan mendapat rata-rata persentase sejumlah $90 \%$ termasuk dalam kriteria sangat baik. Berdasarkan perolehan skor tersebut, maka peneliti menyimpulkan bahwa hasil keterampilan mengetik 10 jari meningkat dibandingkan siklus II, baik kecepatan KPM (Karakter Per Menit) maupun ketepatan (accuracy). Pernyataan ini diperkuat oleh Susanti \& Pramusinto [22] yang hasil penelitiannya menyatakan bahwa keterampilan mengetik 10 jari siswa pada saat kegiatan pembelajaran Otomatisasi Perkantoran tampak lebih terampil daripada siklus II. Hal ini terbukti bahwa tingkat keterampilan yang diamati menggunakan pedoman observasi. Hasil penelitian yang sama juga dilakukan oleh Ninghardjanti \& Yuwantiningsih [11] yang hasil penelitiannya menunjukkan bahwa nilai tes kecepatan dan ketepatan pada siklus terakhir menunjukkan peningkatan apabila daripada siklus sebelumnya. Rata-rata kecepatan yang diperoleh sudah mencapai 110 KPM, sedangkan untuk ketepatan mengetik juga terjadi peningkatan dilihat dari jumlah siswa yang mencapai angka ketepatan 95\%. Dari semula hanya 23 orang, menjadi 32 orang. Artinya hasil kecepatan dan ketepatan pada siklus terakhir sudah terpenuhi secara klasikal.

Keempat adalah tahap refleksi. Setelah rangkaian kegiatan dari awal pelaksanaan hingga pengamatan, terdapat peningkatan dalam aktivitas siswa dan keterampilan mengetik 10 jari siswa dengan menerapkan metode pembelajaran drill, maka aktivitas pembelajaran pada siklus III dianggap selesai.

Berikut ini, dipaparkan grafik aktivitas siswa dan keterampilan mengetik 10 jari siswa dari siklus I, siklus II, dan siklus III berikut ini :

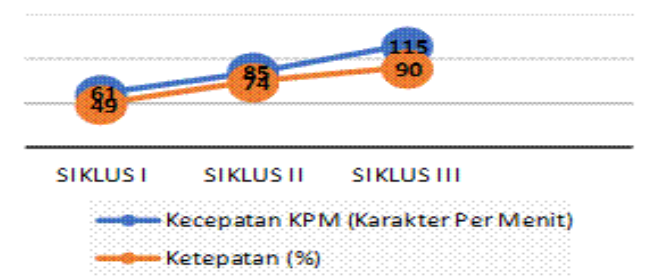

Gambar 1. Aktivitas Siswa Kelas X OTKP 1

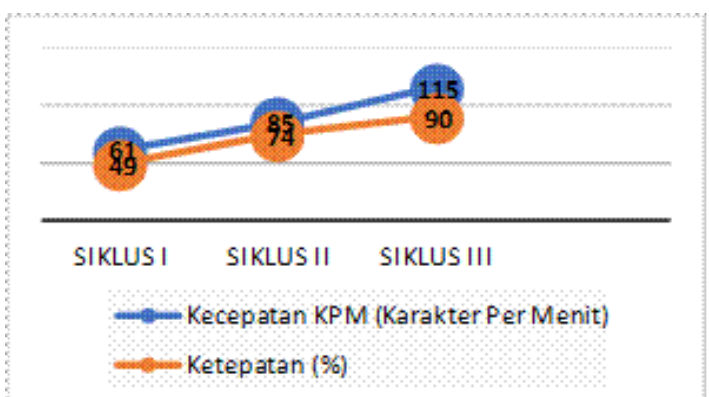

Gambar 2. Keterampilan Mengetik 10 Jari Kelas X OTKP 1

Berlandaskan hasil penelitian yang ditunjukkan pada grafik 1 dan 2 tersebut, menunjukkan bahwa dari siklus I, siklus II, dan siklus III, terjadi peningkatan pada aktivitas siswa dan keterampilan mengetik 10 jari. Peningkatan aktivitas siwa secara keseluruhan pada siklus I mendapat rata-rata skor sejumlah 1,89 (kurang baik), siklus II sejumlah 2,78 (cukup baik), dan siklus III sejumlah 3,72 (baik).

Sedangkan peningkatan keterampilan mengetik 10 jari siklus I pada aspek kecepatan KPM (Karakter Per Menit) mendapat rata-rata skor 61 (cukup baik), sedangkan aspek ketepatan (accuracy) mendapat rata-rata skor 49\% (cukup baik). Siklus II pada aspek kecepatan KPM (Karakter Per Menit) mendapat rata-rata skor 85 (cukup baik), sedangkan sedangkan aspek ketepatan (accuracy) mendapat rata-rata skor $74 \%$ (baik). Siklus III pada aspek kecepatan KPM (Karakter Per Menit) mendapat rata-rata skor 115 (baik), sedangkan aspek ketepatan (accuracy) mendapat rata-rata skor 90\% (sangat baik).

Peneliti juga dapat menyimpulkan bahwa metode pembelajaran drill melalui typing master dapat meningkatkan keterampilan mengetik 10 jari pada mata pelajaran Teknologi Perkantoran kelas X OTKP 1 di SMK Krian 2 Sidoarjo. Sehingga metode pembelajaran drill cocok untuk diterapkan pada kompetensi dasar Menerapkan Pengetikan (Keyboarding) 10 Jari Kecepatan 200 EPM dan Ketepatan 99\% agar siswa dapat terampil dalam mengetik. Hal ini didukung dengan penelitian yang dilakukan oleh Susanti \& Pramusinto [22] yang hasil penelitiannya mengatakan bahwa metode pembelajaran drill melalui typing master mempunyai pengaruh positif serta dapat memberikan peningkatkan dalam keterampilan mengetik 10 jari siswa dalam bidang keahlian Otomatisasi Perkantoran kelas X AP 1. Dengan menggunakan metode pembelajaran drill, siswa akan terbiasa untuk melaksanakan aktivitas secara kontinyu dan berulang-ulang hingga mereka menguasai teori dan keterampilannya. Sehingga metode pembelajaran drill terbukti dapat memberikan peningkatan keterampilan dan hasil belajar jika diterapkan di materi yang cocok dengan metode ini. Hasil penelitian yang senada juga dilakukan oleh Ariyatni, [2] yang hasil penelitiannya menyatakan bahwa metode drill yang diterapkan mampu memberikan peningkatan kemampuan dan pengetahuan siswa kelas X MIPA SMA Negeri 7 Denpasar pada materi memperoduksi teks eksposisi. Hasil penelitian yang sama dilakukan pula oleh Saman [16] yang hasil penelitannya menyatakan bahwa dengan diterapkannya metode pembelajaran drill and practice, keterampilan dan hasil belajar siswa kelas X Akuntansi 1 SMK Muhammadiyah 4 Sragen pada materi komputer Akuntasi spreadsheet meningkat. Puspasari \& Puspasari [13] juga menyatakan 
bahwa metode pembelajaran yang diimplementasikan dapat menjadi salah satu teknik yang mampu meningkatkan kegiatan dan hasil pembelaran jika metode tersebut dikelola dan dilakukan secara kontinyu.

\section{Kesimpulan dan Saran}

Dari pemaparan hasil dan pembahasan tersebut, maka dapat disimpulkan bahwa dengan diterapkannya metode pembelajaran drill melalui typing master dapat memberikan peningkatan terhadap aktivitas siswa dan keterampilan mengetik 10 jari. Pada siklus I, hasil aktivitas siswa secara keseluruhan mendapat rata-rata skor sejumlah 1,89 (kurang baik). Sedangkan hasil keterampilan mengetik 10 jari pada aspek kecepatan KPM (Karakter Per Menit) mendapat ratarata skor sebesar 61 (cukup baik), pada aspek ketepatan (accuracy) mendapat rata-rata skor sebesar 49\% (cukup baik). Aktivitas siswa dan keterampilan mengetik 10 jari di siklus I masih tidak mencapai kriteria baik, maka perlu dilanjutkan ke siklus II. Pada siklus II, hasil aktivitas siswa secara keseluruhan mendapat rata-rata skor sejumlah 2,78 (cukup baik). Sedangkan hasil keterampilan mengetik 10 jari pada aspek kecepatan KPM (Karakter Per Menit) mendapat rata-rata skor sejumlah 85 (cukup baik), pada aspek ketepatan (accuracy) mendapat rata-rata skor sebesar $74 \%$ (baik). Perolehan hasil pada siklus II mengalami peningkatan dibanding siklus I, namun aktivitas siswa dan keterampilan mengetik 10 jari pada siklus II tidak mencapai kriteria baik, sehingga perlu untuk meneruskan ke siklus III. Pada siklus III, hasil aktivitas siswa secara keseluruhan mendapat ratarata skor sejumlah 3,72 (baik). Sedangkan hasil keterampilan mengetik 10 jari pada aspek kecepatan KPM (Karakter Per Menit) mendapat rata-rata skor sejumlah 115 (baik), pada aspek ketepatan (accuracy) mendapat rata-rata skor sejumlah 90\% (sangat baik). Perolehan hasil pada siklus III meningkat dibanding siklus II dan aktivitas siswa maupun keterampilan mengetik 10 jari telah memenuhi kriteria baik. Sehingga siklus III ditetapkan sebagai siklus terakhir oleh peneliti.

Dari kesimpulan tersebut, peneliti memberikan beberapa saran untuk kebaikan di penelitian selanjutnya, diantaranya: 1) untuk memberikan peningkatan keterampilan dalam mengetik 10 jari, maka penggunaan metode pembelajaran drill sebaiknya dilakukan secara terus-menerus oleh guru, sehingga siswa terbiasa dalam mengetik 10 jari; 2) guru harus sering mengadakan tes untuk mengukur keterampilan mengetik siswa; 3) hasil penelitian ini diharapkan dapat melibatkan lebih banyak lagi subjek penelitian, sehingga informasi yang didapatkan dapat memberikan kontribusi terhadap meningkatnya keterampilan mengetik 10 jari siswa.

Batasan dalam penelitian ini, antara lain: 1) subjek penelitian hanya dilakukan kepada siswa kelas X OTKP 1 di SMK Krian 2 Sidoarjo yang berjumlah 22 siswa; 2) kompetensi dasar yang dijadikan penelitian hanya pada Menerapkan Pengetikan (Keyboarding) 10 Jari Kecepatan 200 EPM dan Ketepatan $99 \%$ pada mata pelajaran Teknologi Perkantoran.

\section{Daftar Pustaka}

[1] Afandi, M., Chamalah, E., \& Wardani, O. P. (2013). Model dan Metode Pembelajaran di Sekolah. Jakarta: Perpustakaan Nasional Katalog Dalam Terbitan (KDT).

[2] Ariyatni, N. M. (2018). Penerapan Metode Drill dalam Upaya Meningkatkan Kemampuan Memproduksi Teks Eksposisi Peserta Didik Kelas X MIPA 4 SMA Negeri 7 Denpasar Tahun Pelajaran 2017/2018. Statistika, 7(1): 75-91. https://ojs.ikippgribali.ac.id/index.php/stilistika/article/view/98

[3] Barkaoui, K. (2013). Examining the Impact of L2 Proficiency and Keyboarding Skills on Scores on TOEFL-IBT Writing Tasks. SAGE Journals, 31(2): 241-259. https://journals.sagepub.com/doi/10.1177/0265532213509810.

[4] Djamarah, S. B., \& Zain, A. (2002). Strategi Belajar Mengajar. Jakarta: Rhineka Cipta.

[5] Donica, D. K., Giroux, P., \& Faust, A. (2018). Keyboarding Instruction: Comparison of Techniques for Improved Keyboarding Skills in Elementary Students. Journal of Occupational Therapy, Schools, \& Early Intervention, 11(4): 396-410. https://doi.org/10.1080/19411243.2018.1512067.

[6] Hadi, A. (2019). Peningkatan Hasil Belajar Matematika melalui Strategi Interaktif dengan Menggunakan Metode Pembelajaran Drill pada Siswa Kelas XI MIPA 6 SMA Negeri 16 Makassar. EQUALS Jurnal Ilmiah Pendidikan Matematika, 2(2): 53-61. http://ejournals.umma.ac.id/index.php/equals/article/view/375.

Hasmiati, Jamilah, \& Mustami, M. K. (2017). Aktivitas dan Hasil Belajar Siswa pada Pembelajaran Pertumbuhan dan Perkembangan dengan Metode Praktikum. Jurnal Biotek, 5(1): 21-35. http://journal.uin-alauddin.ac.id/index.php/biotek/article/view/3444.

[8] Kasiani \& Yusuf, M. (2019). Developing Ergonomics-Based Practice System to Improve Students' Typing Skills. International Research Journal of Engineering, IT \& Scientific Research, 5(4): 28-37. https://sloap.org/journals/index.php/irjeis/article/view/688/1187.

Kemendikbud RI. (2015). Salinan Peraturan Menteri Pendidikan dan Kebudayaan Republik Indonesia Nomor 53 Tahun 2015.

10] Mariskha, Alhadi, E., \& Andriyani, T. (2016). Penerapan Program Typing Master dalam Meningkatkan Kecepatan dan Ketelitian Pengetikan 10 Jari Buta. Jurnal Ilmiah Orasi Bisnis, 16: 52-64. https://jurnal.polsri.ac.id/index.php/admniaga/article/view/674/507.

11] Ninghardjanti, P., \& Yuwantiningsih, A. (2018). Peningkatan Kecepatan Mengetik 10 Jari Melalui Penerapan Metode Drill dan Resitasi (Pada Peserta Didik Kelas X Ap 1 SMK Negeri 1 Surakarta Tahun Pelajaran 2018 / 2019). Prosiding Seminar Nasional Pendidikan Administrasi Perkantoran (SNPAP) 2018, hlm. 7-13. https://jurnal.uns.ac.id/snpap/article/view/27870.

[12] Padalia, A. \& Yatim, H. (2020). Implementation of the Drill Method in Learning Art and Culture in High Schools. International Journal of Scientific \& Technology Research, 9(02): 1607-1613. http://www.ijstr.org/final-print/feb2020/Implementation-Of-TheDrill-Method-In-Learning-Art-And-Culture-In-High-Schools.pdf.

[13] Puspasari, D. \& Puspasari, D. (2014). Peningkatan Aktivitas Mahasiswa melalui Peningkatan Metode Pembelajaran Diskusi Kelas Tipe Beach Ball. Prosiding Seminar Nasional ASPROPENDO "Pendidikan Ekonomi Dalam Perspektif Kurikulum 2013 Dan Masyarakat Ekonomi ASEAN", hlm. 337-343. http://repository.unesa.ac.id/sysobarp/files/2018-04-23_Prosiding Seminas 1 Waspodo.pdf.

[14] Rozi, U. A, Indrawati, C. D. S., \& Widodo, J. (2018). Pemanfaatan Program Aplikasi Typing Master untuk Meningkatkan Kecepatan Mengetik Siswa SMK Wikarya Karanganyar Tahun 2018/2019. Jurnal Informasi dan Komunikasi Administrasi Perkantoran, 2(4): 89-100. https://jurnal.uns.ac.id/JIKAP/article/view/38165.

[15] Rusman. (2013). Belajar dan Pembelajaran Berbasis Komputer. Bandung: Alfabeta.

[16] Saman. (2018). Penerapan Metode Drill And Practice untuk Meningkatkan Keaktifan dan Hasil Belajar Komputer Akuntansi Spreadsheet. Edudikara: Jurnal Pendidikan Dan Pembelajaran, 3(1): 43-50. http://www.ojs.iptpisurakarta.org/index.php/Edudikara/article/view/7 7.

[17] Samsudin, S., \& Rahman, H. A. (2016). Pengaruh Metode Pembelajaran Drill, Bermain, dan Kelincahan terhadap Kemampuan Passing dalam Permainan Bola Voli. Jurnal Keolahragaan, 4(2): 
$207-219$.

https://journal.uny.ac.id/index.php/jolahraga/article/view/10899.

[18] Setyaningsih, L. H., \& Muhsin. (2014). Peningkatan Keterampilan Mengetik Sistem 10 Jari Buta dengan Menggunakan Model Pembelajaran Berbasis Komputer Berbantuan Media Typing Master Pada Siswa Kelas X AP SMK Muhammadiyah 01 Pati. Economic Education Analysis Journal, 3(1): 89-93. https://journal.unnes.ac.id/sju/index.php/eeaj/article/view/4146/3784.

[19] Slameto (2015). Penyusunan Proposal Penelitian Tindakan Kelas. Scolaria, $5(2)$ :

60-69. https://ejournal.uksw.edu/scholaria/article/view/17.

[20] Stevenson, N. \& Just, C. (2014). In Early Education, Why Teach Handwriting Before Keyboarding? Early Childhood Education Journal, 42: 44-56. https://link.springer.com/article/10.1007/s10643012-0565-2.

[21] Sulastri, T. (2014). Analisis Mengetik Cepat 10 Jari Menggunakan Teknologi Komputer Berbasis Aplikasi Software Rapidtyping. JURNAL LPKIA, 4(2): 13-18. https://docplayer.info/38989381Analisis-mengetik-cepat-10-jari-menggunakan-teknologi-komputerberbasis-aplikasi-software-rapidtyping.html.

[22] Susanti, A., \& Pramusinto, H. (2015). Peningkatan Keterampilan Mengetik 10 Jari dengan Metode Pembelajaran Drill melalui Typing Master dan Ms. Word Berbantuan Media Job Sheet Pada Kelas X Program Keahlian Administrasi Perkantoran 1 SMK Negeri 2 Semarang. Economic Education Analysis Journal, 4(3): 664-678. https://journal.unnes.ac.id/sju/index.php/eeaj/article/view/8523/5671.

[23] Susilowati, E., Santoso, S., \& Hamidi, N. (2013). Penggunaan Metode Pembelajaran Drill Sebagai Upaya Meningkatkan Prestasi Belajar Akuntansi. Jupe UNS, 1(3): 1-10. https://jurnal.fkip.uns.ac.id/index.php/ekonomi/article/view/2563.

[24] Syaerozi, Supraptono, E., \& Sutarno. (2015). Penerapan Metode Pembelajaran Drill Berbantuan Multimedia Interaktif untuk Meningkatkan Keterampilan Mengolah Data Menggunakan Microsoft Excel 2007. Edu Komputika Journal, 2(2)! 49-58. https://journal.unnes.ac.id/sju/index.php/edukom/article/view/7860.

[25] Tarigan. (2008). Berbicara sebagai Keterampilan Bahasa. Bandung: Angkas

[26] Undang-undang No. 20 Tahun 2003 tentang Sistem Pendidikan Nasional. (n.d.).

[27] Vellayati, S. (2017). Analisis Aktivitas Belajar Siswa dan Aktivitas Pembelajaran Guru pada Mata Pelajaran Kimia (Studi Kasus di SMA Negeri 8 Banda Aceh Tahun 2016/2017). Prosiding Seminar Nasional MIPA III, hlm. 119-126. http://conference.unsyiah.ac.id/SN-MIPA/3/paper/view/842/118.

[28] Wulandari, R. (2013). Analisis Kemampuan Mengetik dengan Sistem 10 Jari Pada Siswa Kelas XI Administrasi Perkantoran di SMK Widya Praja Unggaran. Economics Development Analysis Journal, 2(2): https://journal.unnes.ac.id/sju/index.php/edaj/article/view/1405

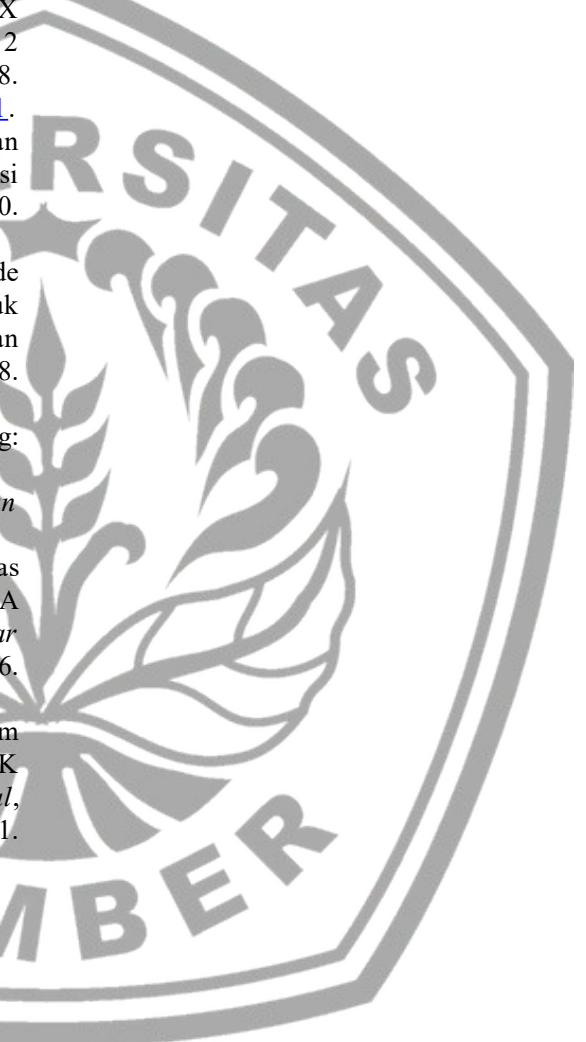

